\title{
Analysis of Financial Statements and Currency Prediction
}

\author{
Minda Muliana Sebayang ${ }^{1}$, Supriyanto $^{2}$, Lisnawati $^{3}$, Rahmaniar ${ }^{4}$, and Ismail ${ }^{5}$ \\ Department of Accounting, Sekolah Tinggi Ilmu Ekonomi IBBI, Medan, Indonesia ${ }^{1}$ \\ Department of Business Administration, Politeknik LP3I Medan, Medan, Indonesia ${ }^{2}$ \\ Department of Financial Analysis, Politeknik Kutaraja, Banda Aceh, Indonesia ${ }^{3}$ \\ Department of Accounting, Politeknik Kutaraja, Banda Aceh, Indonesia ${ }^{4}$ \\ Department of Office Administration, Politeknik Kutaraja, Banda Aceh, Indonesia ${ }^{5}$
}

\{minda sebayang@yahoo.co.id $\left.{ }^{1}\right\}$

\begin{abstract}
This study aims to test the prediction of insurance in the pharmaceutical company which is listed on the Indonesia Stock Exchange using the Altman Z-Score Method. This study uses secondary data on Pharmaceutical Companies, namely PT Indofarma Tbk, PT Kimia Farma Tbk, PT Kalbe Farma Tbk, PT Merck Tbk, and PT Tempo Scan Pacific Tbk 2012-2016 period using analytical technical quantitative descriptive. Liquidity ratios $\mathrm{X} 1, \mathrm{X} 2$, and $\mathrm{X} 3$ profitability, activity X4 and X5. It has the formula Z-Score $=1.2 \mathrm{X} 1+1.4 \mathrm{X} 2+$ $3.3 \mathrm{X} 3+0.6 \mathrm{X} 4+1.0 \mathrm{X} 5$ within the Z-Score assessment criteria $>2.99$ is categorized as a very healthy company. $1.81<\mathrm{Z}$-score $<2.99$ are saved, and the possibility of bankruptcy as much depends on the company's management policy decisions as decision makers. The Z-score $<1.81$ is categorized as a company that has enormous financial difficulties and is at high risk so that the possibility of bankruptcy is very large. The two companies in PT Indofarma in 2012, 2013 and 2015.Two companies in the state of non-financial distress of PT Kimia Farma in 2012, 2015 and 2016, PT Merck Tbk in 2012 -2015. During PT Kalbe Frama and PT Tempo Scan, Pacific is in the gray area.
\end{abstract}

Keywords: Altman Z-Score, Pharmaceutical, Healthy Company

\section{Introduction}

Pharmaceutical companies are companies that are engaged in the development, production, and marketing of drugs that have licenses for medical use. Every company is established with the hope that it will generate profits so that it is able to survive and develop in a very long period of time. This means that it can be assumed that the company will continue to survive and is expected not to experience liquidation [1]. Likewise, the pharmaceutical industry is expected to be able to develop and continue to survive in the face of challenges that originate from within or outside the company itself.

In Indonesia, there have been many large pharmaceutical companies that have developed their respective products. In its activities sharp competition between pharmaceutical companies is inevitable. Therefore, pharmaceutical companies in Indonesia are required to be 
able to compete by making good innovations, promotions and marketing systems, and optimal product quality. The company is also required to continue to improve the effectiveness and efficiency of corporate management by evaluating the company's strategies and policies. Evaluation here is to assess the performance and health of the company in winning competition, economic growth, increasing profits, return on investment, cost efficiency, and creating the economic value of the company.

If seen from the number of Indonesian people reaching 250 million people, and the most important thing is that health is a basic need for everyone, then the prospect of the pharmaceutical industry can be said to be good. However, new challenges arose when the emergence of new government programs in accordance with the mandate of the Law on the National Social Security System and the Law on the Social Security Organizing Agency (BPJS) began to be implemented. The law mandates the holding of a National Health Insurance (JKN) program for all Indonesian citizens.

In 2019, the government targets all Indonesian people to be registered with the BPJS. The poor and cannot pay premiums are paid by the government [2]. The big buzz of the JKN program initially gave hope to the pharmaceutical industry to increase sales. Pharmaceutical companies have high hopes for this program. Programs that are believed to be able to increase the demand for these drugs have indeed succeeded in increasing their sales, but the profit margins continue to decline.

The two state-owned pharmaceutical companies that are big players to meet the drug needs of the JKN program, namely PT IndofarmaTbk and PT Kimia Farma Tbk, are the companies that have experienced more adverse effects from the JKN program [2]. PT IndofarmaTbk and PT Kimia Farma Tbk experienced a decline in profits even though sales increased. In 2014 PT Kimia Farma's profit grew $9.36 \%$ and increased by $13.15 \%$ in 2015 , then decreased in 2016 to 2.2\%. In terms of sales, compared to 2014 and 2015, PT Kimia Farma's sales growth in 2016 was the highest, namely $19 \%$ with total sales of Rp. 5.8 trillion. While in 2015 , the growth was only $6.6 \%$ and in 2014 only $4.14 \%$. Meanwhile, PT IndofarmaTbk lost Rp.17.36 billion. Its profit dropped $364 \%$ from 2015 . Even though sales increased even though it was thin, from the previous Rp. 1.62 trillion to Rp. 1.67 trillion in 2016.

The following data on sales and profit growth at PT Indofarma for the period 2012-2016 can be seen in the column below:

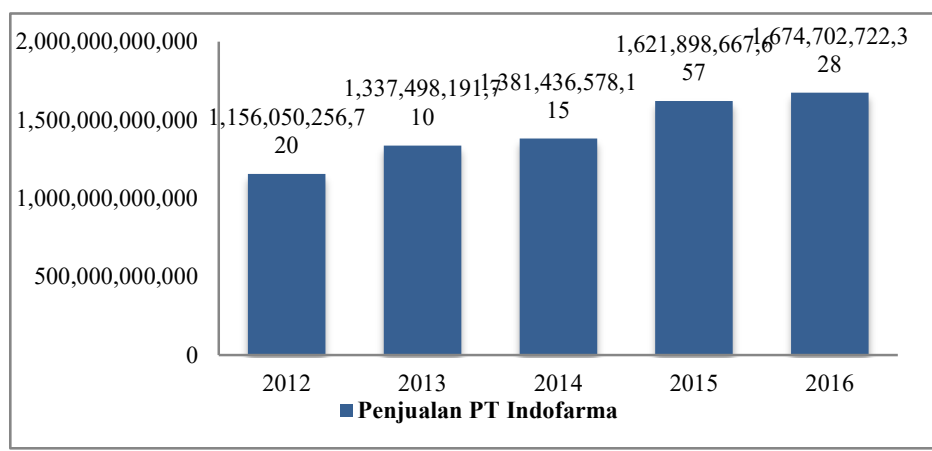

Picture 1 Data on sales progress PT Indofarma in 2012-2016

From figure 1.1 above, it can be seen that PT Indofarma's sales growth in 2012-2016 continued to increase from year to year. 


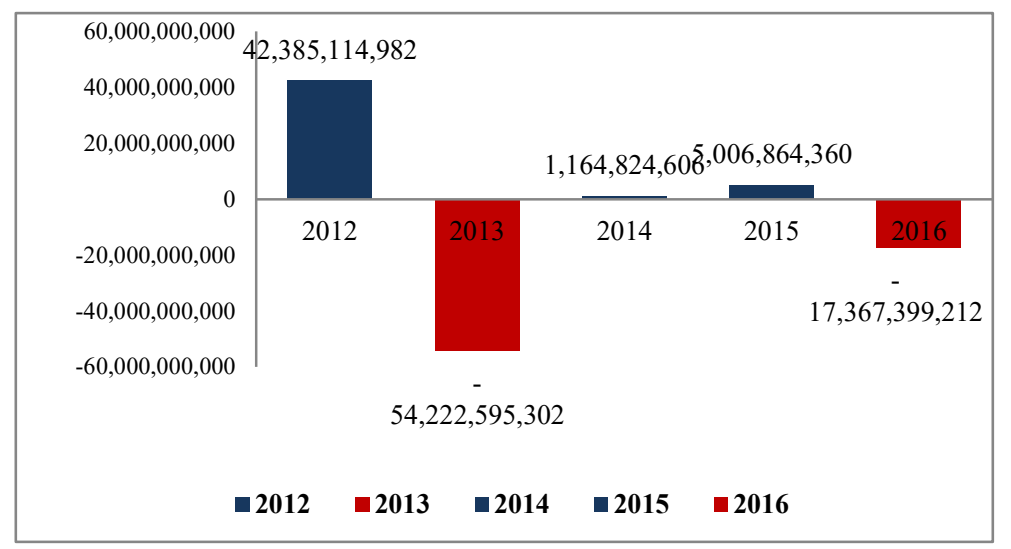

Figure 2 Data on earnings growth of PT Indofarma in 2012-2016

Based on Figure 2 above shows that profit growth at PT Indofarma in 2012-2016 is in an unstable condition. Every year there are significant changes. Even in 2013 and 2016, PT Indofarma suffered a loss. In the activities of the pharmaceutical industry, it cannot be separated from the supervision and regulations set by the government. Procurement of drugs that focus on large quantities of generic drugs has a detrimental effect on the pharmaceutical industry. As a result, pharmacies lose consumers; pharmaceutical wholesalers lose the share of hospitals. While the pharmaceutical industry experienced a decline in growth because it had to operate low prices and low margins [3].

Determination of low purchase prices by the government is another cause of the slowdown in the pharmaceutical industry's profit growth. The high cost of distribution to distribute medicines to remote areas far from factories with the same selling price, joining the JKN program. This low margin also occurs due to the high cost of medicinal raw materials which is $96 \%$ sourced from imports, so the price is very dependent on the dollar. So if at any time the dollar increases, it will increase the company's foreign exchange debt. From some of the problems above, the company must be careful to anticipate where small mistakes will hurt the company. For pharmaceutical companies that are unable to prepare themselves to deal with this situation, their business will shrink and experience financial difficulties and eventually go bankrupt.

Corporate bankruptcy is one phenomenon that often occurs in the business world both influenced by internal and external parties. For example, there is an increase in raw material costs, wage costs, electricity costs or other costs without being balanced with the company's ability, the presence of superior competitor products that affect sales and the inability of managers to carry out company management. These events will indirectly affect the decline in company performance and can cause companies to go bankrupt. The bankruptcy of a public company ( going public ) will harm many parties. These parties, among others, are investors who invest in stocks or bonds, creditors who suffer losses due to default, and employees in the company due to Termination of Employment (PHK), [4].

To overcome and minimize bankruptcy, companies can monitor financial conditions using financial analysis techniques. Analysis of financial statements is a process that is considered in 
order to help evaluate the financial position and results of operations of the company in the present and past, with the main goal to determine the most probable estimates and predictions about the condition and performance of the company in the future. By analyzing the company's financial statements, we can know the condition and financial development of the company. In addition, weaknesses and results that are considered good and potential bankruptcy of the company can also be known.

The problem in this study is how to predict the bankruptcy of Pharmaceutical Industry companies from 2012 to 2016 using the Altman Z-Score method? The purpose of this research is to predict the bankruptcy of pharmaceutical industry companies based on the Altman Z-Score model. With the early detection, evaluation can be carried out to avoid bankruptcy in the company.

\section{Methodology}

Bankruptcy is a condition when a company experiences insufficient funds to run its business. Bankruptcy (bankruptcy) is a condition in which the companies are no longer able to repay their obligations. This condition usually does not just appear in the company; there are initial indications of the company which usually can be recognized earlier if the financial statements are analyzed more carefully in a certain way. The financial ratio can be used as an indication of bankruptcy in the company. In carrying out business activities in fact companies often face financial difficulties or can be interpreted as the inability of companies to pay their financial obligations at maturity which causes the company's bankruptcy [5].

Management of short-term financial difficulties (unable to pay financial obligations at the time of maturity) that are not appropriate will lead to greater problems, namely to become not solvable (the amount of debt is greater than the amount of assets) and eventually go bankrupt [6]. If it is not solvable, the company can be liquidated or reorganized. Liquidation is chosen if the value of liquidation is greater than the value of the company. However, if the company still shows prospects, Reorganization is chosen, and if it continues, it will give greater value than the value of the company if it is liquidated [7].

\section{Factors Causing Bankruptcy}

According to Darsono and Ashari [5], internal factors that can cause the bankruptcy of a company include: Inefficient management will result in continuous losses which in turn causes the company to be unable to pay its obligations. Moral hazard by management, fraud is done by company management can lead to bankruptcy. This fraud can take the form of corrupt management or provide false information to shareholders or investors.

\section{Z- Score Analysis}

A number of studies have been conducted to find out the usefulness of financial ratio analysis in predicting company failure [8]. One study of this prediction is Multiple Discriminant Analysis conducted by Edward I. Altman. Altman uses five types of ratios, namely the Working Capital Ratio to Total Assets, Profits Retained against Total Assets, Before Taxes and Interest on Total Assets, Equity Market Value of Book Value from Debt and Sales Ratio to Total Assets. Mathematically the Altman Z-Score equation can be formulated as follows:

The type of research used in this study is descriptive quantitative, namely research collected in the form of numbers to predict bankruptcy based on the Alt $\mathrm{m} \mathrm{Z}$ Score method, namely the cut off value obtained from financial statements of pharmaceutical 
companies from 2012 to 2016. With using secondary data from the Indonesia Stock Exchange (IDX) in the form of report finance company pharmacy in 2012-2016 there were 9 companies [9] . Data analysis method used in this study is the first Altman Z-Score model (1968), namely for manufacturing companies that go public. Altman found five types of financial ratios that could be combined to see the difference between a bankrupt and non-bankrupt company. Altman Z-Score for pharmaceutical companies that have gone public is determined using the following formula:

\section{Result and discussion}

Results of Altman Z-Score in Pharmaceutical Companies in 2012-2016.

Table 1Analysis Results with Z-Score Method in Pharmaceutical Companies Year 2012-2016

\begin{tabular}{lcccccc}
\hline & \multicolumn{7}{c}{ Z-Score } & \\
\cline { 2 - 6 } \multicolumn{1}{c}{ Issuer } & $\mathbf{2 0 1 2}$ & $\mathbf{2 0 1 3}$ & $\mathbf{2 0 1 4}$ & $\mathbf{2 0 1 5}$ & $\mathbf{2 0 1 6}$ & Average \\
\cline { 2 - 6 } PT IndofarmaTbk & 1,2008 & 1.0391 & 1.8714 & 1.5637 & 1.6917 & 1.4733 \\
PT Kalbe FarmaTbk & 3.9220 & 3.6280 & 3.6945 & 3,5489 & 3,5589 & 3,6704 \\
PT Kimia FarmaTbk & 3.0152 & 2.8024 & 2,4648 & 4,5345 & 4,4458 & 3.4525 \\
PT Merck Tbk & 4,1359 & 4,5591 & 4,9209 & 4,2325 & 3.9892 & 4,3675 \\
& & & & & & \\
PT Tempo Scan PasificTbk & 3,5340 & 3.2275 & 3.1885 & 2,3908 & 3.0872 & 3,0856 \\
\hline \multicolumn{1}{c}{ Source: } & & & & & &
\end{tabular}

Source: data processing, 2018

Information:

Company Estimates in Bankrupt Conditions (Z-Score $<1.81)$

Company Estimates in the gray area or prone condition $(1.81<\mathrm{Z}$-Score $<2.99)$

Company Estimates in Un Bankrupt or Healthy Conditions(Z-Score $>2.99)$

1. In 2012 there was one company in the bankrupt zone based on the calculation of the alt $\mathrm{z}$ - score, namely PT IndofarmaTbk with z-score $1,2008<1.81$.

2. In 2013, the company is in financial difficulty is based on the calculation of Altman, PT Indofarma with a score of 1.0391 or $<1.81$, and the company in a state of a gray area with a score of 2.8024 is he n tara score of 1.81 to 2.99. And three other companies are in a healthy condition or a score of $>2.99$.

3. In 2014 there were two companies in the gray area zone with scores between 1.81 2.99, namely PT Indofarma with a score of 1.8714 and PT Kimia Farma with a score of 2.4648 while the other three companies are in good health.

4. In 2015 there was one company that was bankrupt based on the Z-score calculation, namely PT Indofarma with a score of $1,5637<1.81$, and one company in the gray area zone with a score of 2.3908 .

5. In 2016 only one company experienced financial problems or was in a bankrupt zone, PT Indofarma with a score of $1.6917<1.81$.

From the calculation above, it can be seen what percentage of the company's financial health conditions in a given year. To be presented in the table below: 
Table 2 Pharmaceutical Company Bankruptcy Prediction Percentage Year 2012-2016

\begin{tabular}{|c|c|c|c|c|c|}
\hline \multirow{2}{*}{ Bankruptcy Prediction } & \multicolumn{5}{|c|}{ Year } \\
\hline & 2012 & 2013 & 2014 & 2015 & 2016 \\
\hline Bankrupt & $20 \%$ & $20 \%$ & $0 \%$ & $20 \%$ & $20 \%$ \\
\hline Gray Area & $0 \%$ & $20 \%$ & $40 \%$ & $20 \%$ & $0 \%$ \\
\hline Healthy & $80 \%$ & $60 \%$ & $60 \%$ & $60 \%$ & $80 \%$ \\
\hline
\end{tabular}

Source: Data processing, 2018

Based on the table above, it can be seen that the financial health conditions of pharmaceutical companies over the past five years have fluctuated. In 2013 the financial condition of manufacturing companies declined from the previous year, this can be seen from the percentage of the financial condition of healthy companies fell from $80 \%$ to $60 \%$ and the gray area financial condition increased to $20 \%$. Then in 2014 , the financial condition of pharmaceutical companies began to improve, with no score stating that the company was bankrupt. But in 2015 the financial condition of pharmaceutical companies declined again, namely the percentage of companies that went bankrupt increased to $20 \%$ from the previous year. Then again improved in 2016 from the percentage of healthy conditions increasing from $60 \%$ to $80 \%$ and no company in the gray area.

From the results of the analysis conducted, it can be seen what level of health of pharmaceutical companies listed on the Stock Exchange in 2012-2016 based on the Altman ZScore method. The details are as follows:

1. PT IndofarmaTbk

From the results of the analysis that has been carried out that PT IndofarmaTbk has never been in a healthy condition in five consecutive years with a Z-score $<1.81$ and $1.81<\mathrm{Z}$-Score $<2.99$. So the company was declared to have problems in management and financial structure so that it was predicted to experience bankruptcy based on the Altman Z-Score method. Factors influencing the value of the z-score, namely the profit generated by the company is not optimal and often experiences losses to have an impact on stock prices and the amount of retained earnings each year, and the amount of debt that is too large causes the calculation of each ratio to below.

\section{PT Kalbe Farma}

Based on the analysis of Z-Score calculations that have been made it is clear that PT Kalbe Farma is in good health every year during the observation period. PT Kalbe Farma's Z-Score value is always above 2.99. Even though the value of Z-Score has decreased every year, the company is still in a healthy condition.

3. PT Kimia Farma

In 2013 and 2014 the health condition of the company was in the gray area zone, the ZScore value was between 1.81 - 2.99. But it has improved the value of Z-Score in the following years. 2015 is the highest Z-Score value for this company because it has a high 
MVE to book value of total debt ratio, which is due to the high average stock price and also the number of shares outstanding at the end of the year.

\section{PT Merck Tbk}

The results of the Z-Score analysis every year at PT Merck Tbk state that the company is healthy every year. Although the value of Z-Score always decreases from 2015 to 2016. The value of Z-Score in 2015 decreased due to the value of the sales to total assets ratio decreased from the previous year. Declining sales have an impact on total EBIT so that the EBIT to total assets ratio also decreases.

5. PT Tempo Scan PasificTbk

The health condition of the company Tempo Scan Pacific was in a healthy condition except in 2015. Where in 2015 the Z-Score value of this company was in the gray area zone or between the scores were $1.81-2.99$. This is because each Z-Score ratio is the financial ratio of WCTA $\left(X_{1}\right)$, RETA $\left(X_{2}\right)$, EBITTA $\left(X_{3}\right)$, MVEBVTL $\left(X_{4}\right)$ and STA $\left(X_{5}\right)$ experiencing declines from previous years.

Based on the average value of Z-Score every year, it can be seen that only one company experienced bankruptcy, namely PT IndofarmaTbk and four other companies in a healthy condition, namely PT Kimia Farma Tbk, PT Merck Tbk, PT Kalbe Farma Tbk, and PT Tempo Scan Pacific Tbk. This Z-score value is influenced by each ratio related to company management. The company should manage its assets properly because the asset is able to influence the production of the company and can also measure the level of liquidity of the company in guaranteeing the obligations of each company.

Based on table 4.2 which shows the percentage of bankruptcy prediction of pharmaceutical companies, it can be seen that in 2014 the percentage of companies in bankruptcy conditions decreased to $0 \%$, which means that in 2014 no company experienced bankruptcy based on the predictions of Altman Z-Score. 2014 was the year in which the BPJS program began, where this program greatly affected the value of Z-Score for each company. Because this program increases sales of companies that affect the results of the calculation of the $\mathrm{X}_{5}$ ratio ( Sales to Total Assets ). In accordance with what was discussed in the research background, the JKN program succeeded in increasing sales but caused a decline in profit margins because companies had to operate low prices and low margins. This is reinforced by the decline in the financial ratio of pharmaceutical companies in 2015 , the ratio was marked by the existence of companies that were in the score of bankruptcy because the profits obtained by the company declined from the previous year. This can be seen in Appendix 2 which shows that sales of each pharmaceutical company tend to increase and profits tend to decline in some companies.

Based on a statement expressed by Vincent Harijanto as Chairman of the Pharmaceutical Business Association of Trade and Industry (GP) Pharmacy, the pharmaceutical industry is now under pressure because the BPJS drug has been set by the government at a low price. But on the other hand, the pharmaceutical industry cannot recklessly raise the price of drugs. Because it is feared that it will be difficult to compete with the BPJS drugs [10].

Based on the statement, it can be seen that the BPJS program not only has an adverse impact on companies that produce drugs subsidized by BPJS, but also cause intense competition among pharmaceutical companies because they have to compete with cheap BPJS drug prices. In fact, the cause of a company's financial health condition is more determined by the internal party of the company itself. The company must have a good management strategy and the company must be able to face threats from outside the company itself.

This is evidenced by the value of Z-Score in each pharmaceutical company which shows that not all companies that take part in the BPJS tender program are in the gray area score and 
are bankrupt. PT Kimia Farma is one of the companies that participated in supplying BPJS drugs that were able to maintain financial health conditions even though they had been in the gray area zone in 2013-2014. Then it improved in 2015 and 2016 due to the increase in the average price of the company's shares which affected the MVE ratio to a value of total $\operatorname{debt}\left(\mathrm{X}_{4}\right)$.

The company's image greatly influences the sustainability of the company itself. With a good image, the company will get attention from investors who will invest. This is evidenced by the increase in the value of Z-Score in Indofarma companies in 2016, which experienced an increase in value from the previous year, even though the Indofarmacompany had negative profits in 2016. This is due to the high stock prices in 2016 making the market value of equity value PT Indofarma is high.

A good image will also affect the product's assessment by the customer. PT Merck Tbk is a well-known company in the production of expensive pharmaceutical drugs. The production of drugs produced by PT Merck Tbk is one type of drug that has no substitute goods. One of them is Viagra medicine which has a very expensive and monopoly selling price. PT Merck Tbk is also well-known for its research and discoveries that are well-known in the pharmaceutical field that is able to contribute to the community at large. So that even though they do not contribute much in supplying BPJS drugs and still produce patent drugs, PT Merck Tbk is able to compete with other pharmaceutical companies.

The five variables used to calculate the Z-score value of a pharmaceutical company between variables with one another has a relationship that influences the value of large working capital indicating the productivity of company assets that are able to generate large operating profits as expected by pharmaceutical companies. With the increase in the company's operating profit, it will attract investors to invest in the company so that the company's retained earnings will increase. The profit of a period is certainly very influential for the next period because it will affect the amount of retained earnings for the next period. The increase in retained earnings and working capital owned by the company will increase the total sales of pharmaceutical companies. Vice versa, if the working capital owned by the company gets smaller, the company will get a small profit. If the company experiences this, it will lead to financial difficulties and if this situation continues then the company will experience bankruptcy.

\section{Conclusion}

Analysis of the prediction of a bankruptcy of pharmaceutical companies based on financial statements from 2012 to 2014 concluded that PT IndofarmaTbk was declared experiencing management problems and financial structure because the Indofarma company's Z-score for five years was always $<2.99$. While PT Kimia Farma Tbk was in the gray area condition in 2013-2014, and PT Tempo Scan Pacific was in the gray area condition in 2015, even though it was not in a bankrupt condition and there had been an improvement in value in the following year the company must continue to improve management towards improving financial conditions so that companies can maintain the health condition of the company. In addition, performance improvements are needed by every company so that it is less likely to experience bankruptcy.

From the prediction data of the Altman Z-Score bankruptcy method in pharmaceutical companies in 2012-2016, there is only one company that is in a bankrupt condition, namely $\mathrm{PT}$. IndofarmaTbk, but other companies are often in a gray area, which is a condition where the company has the potential to experience financial distress and requires special attention. 


\section{References}

[1] A. P. Octarie, “Analisis Penerapan Metode Altman Z-Score dan Zmijewski Pada Perusahaan Manufaktur Sektor Industri Barang Konsumsi Sub Sektor Farmasi Periode 2009-2013," Universitas Hasanuddin Makasar, 2015.

[2] U. Nur Zuhra, "Program JKN Gagal Dongkrak Laba Perusahaan Farmasi," Tirto, 2017. [Online]. Available: https://tirto.id/program-jkn-gagal-dongkrak-laba-perusahaanfarmasi-covp.

[3] Gloria, "BPJS Kesehatan Pengaruhi Industri Farmasi secara Signifikan," Universitas Gadjah Mada, 2016. [Online]. Available: https://www.ugm.ac.id/id/berita/11045bpjs.kesehatan.pengaruhi.industri.farmasi.secara.signifikan.

[4] R. Mulyadi, "Effect of Profitability Ratio on Performance Evaluation of Altman ZScore Model on Pharmaceutical Companies on the IDX," Account. J., vol. 3, no. 1, 2016.

[5] A. Darsono, Pedoman Praktis Memahami Laporan Keuangan. Yogyakarta: Andi Publisher, 2005.

[6] S. Munawir, Analysis of Financial Information. Yogyakarta: Liberty, 2002.

[7] M. M. Hanafi and A. Halim, Analisis laporan keuangan. Yogyakarta: AMP-YKPN, 2005.

[8] I. M. Kamal, "Bankruptcy Prediction Analysis on Go Public Banking Companies on the Indonesia Stock Exchange Using the Altman Z-Score Model," Hasanuddin University, Makassar, 2012.

[9] S. Kurniawati, "Bankruptcy Analysis with Altman Z-Score Model in Metal \& Similar Subsector Companies in IDX 2014 Period," J. Audit. Financ. Forensic Account., vol. 5, no. 1, pp. 1-16, Nov. 2017.

[10] Y. Artha Uly, "Industri Farmasi Tertekan Akibat Murahnya Harga Obat BPJS," Okezone, 2018. [Online]. Available: https://economy.okezone.com/read/2018/07/11/320/1921075/industri-farmasitertekan-akibat-murahnya-harga-obat-bpjs. 